\title{
Fuzzy Sovereignty: Rural Reconstruction in Afghanistan, between Democracy Promotion and Power Games
}

\author{
ALESSANDRO MONSUTTI \\ Graduate Institute of International and Development Studies, Geneva
}

OVERLAPPING SOVEREIGNTIES IN AFGHANISTAN

To a Western audience, Afghanistan evokes images of poverty, mass migration, violence, and religious extremism, and it may therefore seem a strange place to study the effects of democracy promotion. Yet the country is the destination of thousands of experts who conceive their endeavor within the framework of a struggle between the values of modernity (democracy, human rights, women's empowerment, secular education, and accountability, to mention but a few), the archaisms of tradition, and the corruption of the state system. Such an international involvement may recall the presence of the Soviets in the 1980s who, in addition to their harsh military occupation, implemented a development policy consisting of female emancipation, literacy campaigns, and land reform. But the sovereignty of the Afghan state has been shaped recurrently by external actors. ${ }^{1}$ Building on the polity that Pashtun tribes created during their military advances of the mid-eighteenth century, modern Afghanistan came into being in the second half of the nineteenth century through the action of colonial powers. Only then was the name of the country established,

Acknowledgments: This paper is based on field research partly funded by the Agence nationale de la recherche, France. I am grateful to the Program in Agrarian Studies at Yale University, where I had the opportunity to develop and present my work during the academic year 2008-2009. I am in debt to the people who have provided intellectual support and insightful comments on earlier versions of this paper (in alphabetical order): Susanna Fioratta, Yan Greub, Shah M. Hanifi, Karen Hébert, Kay Mansfield, Keely Maxwell, Boris-Mathieu Pétric, Fenneke Reysoo, Laura Sayre, James Scott, K. Sivaramakrishnan, and Nandini Sundar. Special thanks must go to the anonymous CSSH reviewers, and to CSSH Managing Editor David Akin who worked patiently with me to improve the style and clarify many of my arguments.

${ }^{1}$ I use "sovereignty" in this text in the classic sense of the "ability to kill, punish, and discipline with impunity wherever it is found and practiced" (Hansen and Stepputat 2006: 296), but also the capacity to protect through benevolence and welfare programs. 
when Russians and British fixed its frontiers and made it a buffer state between their respective possessions in Central Asia and the Indian subcontinent. ${ }^{2}$

A growing body of literature has analyzed the tension between the pervasiveness of the nation-state as the organizational entity of today's international politics and the emergence of overlapping sovereignties linked to the global action of institutional actors, such as international and nongovernmental organizations, philanthropic foundations, think tanks, and of course military forces. The case of Afghanistan is simultaneously exemplary and unique. The country is a formal democracy with an elected president and parliament, but it depends almost fully on a foreign presence for the delivery of welfare services and for its security.

The Eisenhower Study Group (2011) estimates at US\$2.3 to 2.6 trillion the costs of war paid by the American government in Iraq, Afghanistan, and Pakistan since September 2001. ${ }^{3}$ The military is not concerned only with fighting; it is progressively adopting the explicit objective of using aid to win hearts and minds, gain support from local populations, and isolate insurgencies. The U.S. Army's main tool for funding stability operations and development projects in Iraq and Afghanistan is the Commander's Emergency Response Program (CERP). Its budget for Afghanistan jumped dramatically from \$40 million in 2004 to approximately $\$ 1$ billion in 2010. Overall, 60 percent of the U.S. reconstruction funds for Afghanistan have been allocated via the Department of Defense, compared with a modest 18 percent via USAID, with the rest managed by the Department of State and other agencies (Johnson, Ramachandran, and Walz 2011: 7, 9). The military operations in Afghanistan and elsewhere increasingly impinge on the traditional space of bilateral development agencies of the main donor countries and sometimes compete with them. Given the persistent insecurity in many developing countries, more and more regions are beyond the direct reach of UN agencies and NGOs. The extent to which the military, as a global actor, contributes to the reshaping of local power structures and sovereignty deserves more study. Unfortunately, in the growing literature on insurgency and counterinsurgency issues, ${ }^{4}$ recent writings on Afghanistan have been dominated by a policy-oriented approach that is not built on independent field research. ${ }^{5}$ It largely ignores the theoretical debates on subaltern studies, postcolonialism, and globalization that currently animate the social sciences. Only a few anthropologists have analyzed the social dimension of the massive presence of foreign troops in Afghanistan, the most notable exception being David Edwards' research on the Human Terrain Systems (2010).

\footnotetext{
2 See Schetter 2005; and Hanifi 2011.

3 The wars will eventually cost between $\$ 3.7$ and 4.4 trillion dollars. See also http://costsofwar. org/ (last consulted 28 Nov. 2011).

4 Within this enormous and often redundant literature, Bhatia and Sedra (2008), and Jones (2009) stand out.

5 Among a multitude of reports and books, see Danspeckgruber and Finn (2007), or Rotberg (2007).
} 
The present study does not focus on the role of the military, but instead presents an ethnographic perspective on the reconstruction effort's impacts on Afghan society. My purpose is to contribute to debates on how national sovereignty, especially in contexts of conflict and post-conflict, is influenced by the circulation and the use of resources brought in through transnational channels. I examine how political games at national and local levels are evolving in relation to the presence of UN agencies and NGOs that are implementing reconstruction projects, and I also describe how new values and behaviors are being fostered. My case is the National Solidarity Program (NSP), a rural rehabilitation program funded primarily by the World Bank and celebrated by the donors and implementing partners as the success story of the reconstruction effort. Though the NSP budget-less than \$1 billion between 2003 and 2010 - may appear inconsequential when compared to military spending, the program's significance must be considered in the context of several decades of humanitarian action and development projects that have played an essential role in the life of millions of Afghans, as recipients, trainees, or wage-earners. As we will see, the NSP's ambition is to empower local communities across the entire country by encouraging the emergence of new decision-making mechanisms at the village level.

I draw upon the classical, methodological, and theoretical premise that power derives from controlling and redistributing resources. All actors in the Afghan political arena seek, through different strategies and means, to increase their influence and constituency by tapping available resources that circulate, in large part, along transnational networks. As has been widely acknowledged in anthropological studies of development, social actors elaborate strategies to gain control over the resources channeled by aid organizations. But projects such as the NSP also have more subtle effects. The people involved may pursue their own interests, but many internalize new values and codes of conduct, and as a result, the way they perceive themselves and are perceived by others is progressively transformed. Indeed, the instrumentalization of aid is not the whole story. People's subjectivity is imperceptibly modified by their participation in various activities funded and monitored by United Nations agencies or international NGOs, whose goal is to promote new values, and to empower and convince. This fact can be grasped via Foucault's notion of "governmentality": the "government of mentality."

The "fuzzy sovereignty" that emerges in places like Afghanistan cannot be reduced to a form of Western imperialism, or univocally explained as local actors using and manipulating external resources for their own sake. I show this in what follows through an examination of the different kinds of transnational networks that can be distinguished in Afghanistan. Again, I concentrate on humanitarian action and development as carried out through the NSP, particularly the NSP national conference held in Kabul in November 2007, which brought together most of the protagonists that interest us. Through the 
venue of the conference, I successively explore various dimensions of my topic: the narrative of progress and international solidarity put forward by the Afghan authorities; the subjectivity of people involved in the program and the acquisition of new body gestures and codes of conduct through participation in discussion workshops; the reconfiguration of the social geography of the Afghan rural world; discrepancies between how NSP promoters view the rural world and the actual social dynamics of that world; and the program's significance for national politics. At the end I will return to issues of emerging forms of sovereignty and governmentality that are particularly visible in a country such as Afghanistan. Though I employ Afghanistan as a case study, I will highlight social and political processes also observable in Asia, Africa, and Latin America.

\section{THE EMERGENCE OF A TRANSNATIONAL GOVERNMENTALITY}

In a frequently quoted, seminal essay that explores the contemporary politics of globalization, Ferguson and Gupta (2002) make two points important to us here. First, states are spatialized through metaphors and symbols, but also through mundane bureaucratic practices that are characterized by verticality (the state is above civil society, and then local communities and families) and encompassment (a series of ever-widening circles from the family, to the local community, and then nation-states and the international community). In such a mainstream model, civil society is conceived as a zone of mediation between the upper level of the state and the ground level of local groups. Ferguson and Gupta's second point is to stress the rise of networks of international and nongovernmental organizations to which a loose world of activists gravitates. This vast system is diverse: it includes the United Nations Development Program; the United Nations High Commissioner for Refugees (UNHCR); the World Health and World Trade Organizations; the World Bank; the International Monetary Fund; party foundations like the National Democratic Institute for International Affairs, the International Republican Institute in the United States, the Friedrich Ebert Stiftung and the Konrad Adenauer Stiftung in Germany; charity foundations like the Open Society Institute of the speculator and philanthropist George Soros; and think tanks such as the Brookings Institution and International Crisis Group. There are also other nonprofit institutions that promote democracy, for example the International Foundation for Electoral Systems, which logistically helped to organize and monitor elections in places such as Afghanistan, Iraq, Kyrgyzstan, or Ukraine. We must also include in the picture environmentalist groups, Christian and Islamic transnational religious groups, and so-called "grassroots associations." All these structures constitute networks that span various countries, and by their actions they complement and sometimes challenge more familiar forms of state spatialization and participate in a reconfiguration of governmentality between states and non-state entities. All contribute to the transnationalization of state-like 
practices, and to the emergence of new relations between politic affairs and territory.

Ferguson and Gupta base their analysis on a comparison between India and Africa, in each of which the power balance between the state and NGOs is different. They point out how neoliberal policies celebrate the virtues of civil society and tend to consider the state an institution incapable of managing social life. Their main conclusions are valid for many other places. In a country such as Afghanistan, the organizations of civil society ${ }^{6}$ are neither below the state nor will they replace it - they will continue to coexist with it (2002). These organizations are supported by a vast, transnational apparatus of governmentality that blurs the distinction between the local and the global, the national and the international.

Humanitarian assistance and development are social phenomena in their own right and they participate in the diffusion of transnational governmentality. They channel resources and generate power structures that are crucial elements of the social landscape and political struggles in both urban and rural Afghanistan. As such, we need to study the actions of international and nongovernmental organizations without our description or analysis being directly or indirectly trapped by a desire to improve existing practices. ${ }^{7}$ Rather, we should examine them in order to understand how they set up a body of foreign experts and local staff that may complement or compete with state services and jobs. Classic Weberian social sciences regard the development of bureaucracy as a process that takes place in a world of nation-states, and leads to more rational and efficient forms of organization. By contrast, contemporary scholarship increasingly acknowledges the existence of overlapping and often competing sovereignties within and across national borders (Hansen and Stepputat 2005; 2006), which involve benevolence and welfare programs as much as coercion and repression. These layered and segmented sovereignties are highly visible in Afghanistan, more spectacularly so since the fall of the Taliban in late 2001 led to establishment of a central government backed by the international community.

POST-TALIBAN AFGHANISTAN: A QUEST FOR RESOURCES AND POWER

Since the American-led military coalition ousted the Taliban from Kabul and the major urban centers, Afghanistan has experienced dramatic changes. The

${ }^{6}$ A canonical definition is proposed by the Afghan Civil Society Forum (ACSF): "Civil society includes those who come together voluntarily to participate in civic affairs for the common good, without consideration for personal and political gain, and in peace" (quoted in Afghanistan Research and Evaluation Unit 2004: 4). Considering the weakness of grassroots organizations in Afghanistan (except for the networks of some religious leaders), civil society there tends to be understood in a narrow sense as the NGOs funded and logistically supported by external donors and the people who gravitate around them.

7 We may follow Tania Li when she writes, "The position of critic and programmer are properly distinct" (2007: 2). The experts who are promoting development and assistance are not in a structural position that allows them to take their practices as an object of analysis. 
democratization process conducted under the guidance of the international community resulted in the holding of two loya jirga, or Grand Assemblies, in June 2002 and December 2003-January 2004, followed by presidential and legislative elections in October 2004 and September 2005, and again in August 2009 and September 2010. After a period of hope, these formal successes proved unable to prevent a further deterioration of the situation in the field. This failure is usually blamed on Afghan government mismanagement and corruption, the inefficiency of reconstruction projects, the resurgence of the Taliban, rampant criminality, and the explosion of drug production and trafficking. Many observers are haunted by the question, "What went wrong?" Most consider the recent success of the insurgency to be a corollary of the failure of the reconstruction process. ${ }^{9}$

Infrastructures - already weak in the past - have suffered greatly since the communist coup of 1978. Except for poppy cultivation, agricultural productivity remains low, while Afghanistan's population growth rate is one of the highest in the world. The government has little ability to collect revenue, and the national budget is heavily subsidized by international aid. Considering the degree to which sovereignty has been displaced by the massive international presence, we can here speak, without exaggeration, of a "globalized protectorate." 10 The Afghan state lacks two things necessary to building domestic and international political legitimacy: a set of founding principles stemming from a shared narrative of the past, and the capacity to generate revenue and have transparent forms of redistribution. As long as these two aspects (among many others) are not tackled successfully, no solution to the crisis is likely. But while the presence of multiple external resources manifests the government's strong dependency on international aid and support, ${ }^{11}$ it also gives political actors access to new means to build and maintain their authority.

Many observers, stuck in a normative perspective, have proved unable to analyze the structural factors at work in Afghanistan. The present study is structured by an analytical grid of four transnational networks that bring material and non-material resources into Afghanistan, as shown in figure $1 .{ }^{12}$ These must be understood as ideal-types, and they largely overlap on the ground. This phenomenon is by no means unique to Afghanistan, but its scale there probably is.

${ }^{8}$ See Semple 2009.

9 E.g., Tarzi 2008.

${ }_{11}^{10}$ I borrow the expression from Pétric 2005.

11 This situation is reminiscent of the Kabul amirs at the end of the nineteenth century; their power depended, to a large extent, on British subsidies that could influence in a direct or indirect manner (Hanifi 2011).

${ }^{12}$ The term "transnational" refers to links that cut across national borders. It is distinct from "international," which refers to relations between states and governments. 


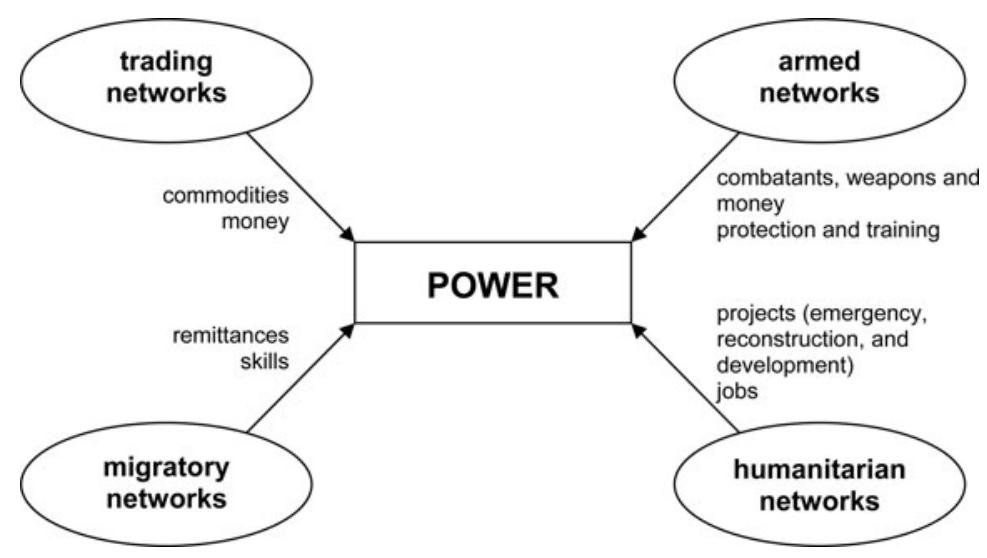

Figure 1 Transnational Networks and Power.

The first kind of network is based on migration. In recent decades a large proportion of the Afghan population has fled from violence, mostly to neighboring countries but also to the Arabian Peninsula and the West. The UNHCR in 1990 counted over six million Afghan refugees, mostly distributed between Pakistan and Iran, and 1.5 million internally displaced people (Coleville 1998). They represented 40 percent of the "people of concern" who at that time fell under the mandate of the UN agency. Despite subsequent massive waves of returns, a large number of people of Afghan descent still live abroad. Moreover, repatriation does not necessarily mean the end of displacement. Afghans have developed very efficient social strategies based on the dispersion of kin group members and ongoing circulation. After many years, the migratory movements have become highly organized, and the resulting transnational ties are now a major and even constitutive element in the social, cultural, and economic life of Afghans.

The second type of network is those based on trade. These networks are dominated by illegal activities - the smuggling of narcotics and manufactured goods. All kinds of consumption items - from household electrical goods, to televisions and computers, to motor vehicles-flood the national markets, and some are subsequently shipped to the bordering countries. The quantity of goods involved is enormous. The scale of the drug economy, in particular, cannot be exaggerated; the country is the primary global source of opium, producing 92 percent of the world's supply in 2007 (UNODC 2011). Poppy cultivation is concentrated in the southern provinces where anti-government forces are the most active, but the export routes are remarkably diverse and reach across regions where the insurgency is not much present, making the drug economy a pervasive phenomenon. The trading activities also include the 
hawâla system used by simple laborers, shopkeepers, and businessmen to remit money to or from Afghanistan through the circulation of goods across international borders (Monsutti 2004; 2005). This means that trading networks are indistinguishably mingled with migratory networks.

Third are non-state armed networks. These include Islamist networks that allow insurgents to receive weapons, money, fighters, and logistic support from a nebulous, global world of sympathizers, but they also include private security contractors, which employ tens of thousands of personnel in Afghanistan and sell their services to NGOs, embassies, business companies, and even national armed forces (Rimli and Schmeidl 2007). In 2010, President Karzai repeatedly called for a ban on these firms but met with intense resistance from both the diplomatic and humanitarian milieus, revealing limits on the state sovereignty. Considering such weakness, the central government is just as dependent as are the insurgency groups on military and logistical support from outside. ${ }^{13}$ Propaganda strategies also show a striking similarity, and the foreign military directly competes with Islamist groups for "winning the hearts and minds" of Afghanistan's peoples.

Finally, there are the humanitarian networks. UN agencies and NGOs fund and implement projects among refugees and returnees in both rural settlements and urban neighborhoods. Many actors in these networks have denounced the "mixing of genres" that results in the instrumentalization of aid in support of a stabilization agenda aimed at rallying the population's support for counterinsurgency objectives. These critics stress how, for several decades now, humanitarian organizations have provided health care, education, training, and employment. Their actions have favored the rise of a class of people who now occupy a growing place in the public arena in Afghanistan. But if only some families have successfully moved into the humanitarian professional niche, every Afghan has been affected by the activities of an NGO. Overall, all Afghan men and women-ministers and members of the parliament, traffickers and commanders, human rights' activists and Islamic militants, security guards and taxi drivers, shopkeepers and farmers - are connected in one way or another with the outside world. Although these actors deploy diverse strategies, they all rely on transnational links to promote their visions and interests.

It is difficult to conduct participant-observation research into Islamist networks and drug trafficking, given their illegality, elusiveness, and secrecy. ${ }^{14}$ Though I have conducted ethnographic study of migrants' networks (Monsutti 2004; 2005; 2009), I will focus here on humanitarian action. International and

13 Note, however, that it is not strictly speaking a transnational phenomenon because the relations in this case are at the interstate level.

14 Most of the existing texts are by political scientists, sociologists, or journalists. See, for example, Abou Zahab and Roy 2003; Cooley 2000; Devji 2005; 2008; Marsden 1998; Rashid 2002; and Roy 2004. 
nongovernmental organizations produce many texts that blur the boundary between research and consultancy, ranging from preliminary project-feasibility reports to activity reports, internal notes, and independent evaluations. ${ }^{15}$ However, humanitarian action in Afghanistan has been insufficiently subject to research in its own right.

The National Solidarity Program offers an ideal entry point from which to examine evolving sovereignties and the penetration of novel bureaucratic practices in rural Afghanistan. It funds a series of community-based development projects, has in principle a national coverage, and in the official rhetoric of the donors, the Afghan state, and the implementing organizations it is presented as the success story of the reconstruction effort. The NSP's explicit agenda is to simultaneously convey resources to the local level and promote the values of participatory democracy. A study of the program can illuminate the subtle tension that exists between the instrumentalization of aid by local actors and the spreading of transnational governmentality.

AN IDEAL OF COMMUNITY BUILDING: THE NATIONAL SOLIDARITY PR O G R A

The NSP is the main project of rural reconstruction underway in Afghanistan. ${ }^{16}$ Launched in 2003, it is financed primarily by the World Bank through the Afghanistan Reconstruction Trust Fund (ARTF) and is administered by the Ministry of Rural Rehabilitation and Development (MRRD). Because neither the World Bank nor the MRRD have a presence in rural villages, the NSP is implemented on a district basis by twenty-nine "Facilitating Partners" that comprise one UN agency, twenty-one international NGOs, and seven national NGOs. Officially, all are selected through a competitive process. ${ }^{17}$

The program establishes local Community Development Councils, or $\mathrm{CDCs},{ }^{18}$ that should be elected democratically by secret ballot. Their function is to discuss development priorities and propose concrete projects with the support of the Facilitating Partner. According to the official rhetoric: "The National Solidarity Programme (NSP) was created by the Government of Afghanistan to develop the ability of Afghan communities to identify, plan, manage and monitor their own development project" (NSP 2006: 1).

\footnotetext{
15 On the NSP alone, see ACTED (2007), Barakat (2006), Beath et al. (2010), and Nixon (2008), who do not always avoid a hagiographic bias. Most of these authors have financial ties with the program or its donors.

16 See the sites: www.mrrd.gov.af/ and www.nspafghanistan.org/.

17 See http://www.nspafghanistan.org/facilitating_partners.shtm.

18 In Persian, shurâ-ye enkeshâfi. "Community Development Council (CDC): A group of community members elected by the community to serve as its decision-making body. The CDC is the social and development foundation at the community level, responsible for implementation and supervision of development projects and liaison between the communities and government and nongovernment organizations" (NSP 2006: vi).
} 
The overall organization of the program is pyramidal, with each step of the implementation as well as each partner subjected to crisscrossed monitoring and evaluation, creating a structure of action at the national scale of patronage and power. The NSP works to enhance inclusive forms of local governance and to alleviate poverty, and has instituted measures at each stage of the process to ensure the participation of women. It is presented as being based on Afghan traditions, such as hashar and jirga, ${ }^{19}$ as well as on the Islamic values of unity, equity, and justice. A first phase, from May 2003 to March 2007, reached 17,300 communities; a second, from April 2007 to March 2010, was projected to reach 4,300 additional communities, for a total of 21,600 communities, or 90 percent of Afghanistan's 24,000 villages or rural settlements. ${ }^{20}$ The overall budget was US\$929 million. ${ }^{21}$ Communities can receive AFS 10,000 (about US\$200) per family, up to a maximum of AFS 3,000,000 (about US $\$ 60,000)$ per community. This gives local populations an incentive to make sure the community's size does not exceed three hundred families. Afghans conceive a domestic unit as one of people who eat food cooked in the same pot, and the unit often includes more than two generations. However, with a curious lack of sensitivity to the Afghan cultural context, official NSP documents define the family as "a husband, a wife (or wives), and unmarried children; or a single head of household (male or female) and his/her unmarried children" (NSP 2006: 7).

Many actors and observers think the NSP can produce positive changes. A vast corpus of reports stresses the merits of the program. Hamish Nixon (2008) thinks that it is necessary to overcome the distinction between governance and development. He considers that the CDCs have the potential to assume more responsibility, although several logistical issues must be addressed. In such a perspective, the role of these local councils needs to be formalized beyond the NSP mandate, to allow them to become effective governance institutions at the village level. Others are more skeptical. Jennifer Brick (2008), though

19 A hashar is a kind of collective voluntary work meant to assist a neighbor or improve community infrastructure. The term is wrongly transcribed ashar in the official texts in English and this error has permeated the related development literature. "Jirga/Shura: traditional Afghan village councils comprised of elders. Under the NSP, communities are free to elect community members of their choosing to their Community Development Council, which may or may not include members of existing jirgas or shuras" (NSP 2006: vii).

${ }^{20}$ The various terms used in English- "community," "village," "rural settlement" - and their Persian equivalents, such as qaria, are not clearly defined. In official documents, the total number of villages in Afghanistan has fluctuated between twenty thousand and forty-two thousand. Even if no consensus has been reached, it has been decided that a community must have at least twenty-five families to be eligible for a block grant.

21 This amount may seem minuscule compared to the aforementioned military expenses, but its full significance can be appreciated by comparison with domestic taxation. In 1387 (2008-2009), for instance, the Afghan central government was only able to collect 18,860 million afghanis, less than US\$400 million, corresponding to 68 percent of its current revenue (data provided by the Afghan Ministry of Finance: http://mof.gov.af/en/page/422). 
she worked for the same research organization as Nixon (the Afghanistan Research and Evaluation Unit ${ }^{22}$ ), argues that the mere election of councils' members is insufficient to assure their accountability. Although the CDCs are supposed to derive their legitimacy from their local populations, their very existence depends on the influx of resources channeled through the program. Brick demonstrates how these councils can compete with existing functional mechanisms, such as elders' deliberative assemblies, which have proved to be relatively efficient in mediating disputes and providing public goods.

By identifying beneficiary communities, the NSP produces a new division of Afghan territory and thus alters the pre-existing principles of social organization. The ideal of community-building and participatory democracy applied by the NSP is based on the supposed virtue of a civil society, understood here as Western-sponsored NGOs and the people engaged in the forms of social mobilization directly propelled by the reconstruction projects. By contrast, here I will analyze local groups in Afghanistan as arenas where different political entrepreneurs are competing for scarce resources and struggling for power, sometimes through violent means.

\section{A NARRATIVE OF PROGRESS AND INTERNATIONAL SOLIDARITY}

In the fall of 2007, I attended the NSP's national conference at Kabul. The conference is a total social fact in the classical Maussian sense. That is, it weaves together the national, regional/local, and personal/subjective levels and brings together most of the actors involved (representatives of the government, the donors, NGOs, and the rural population). It also stages relations of power, reveals economic dependencies, examines individual and collective rights, and diffuses new codes of conduct. The 2007 conference convened in the very place where the June 2002 and December 2003-January 2004 loya jirga were held. This location symbolizes the practices of deliberation that accompany the (re)construction of the Afghan state that is taking place under the direction of the international community. Delegates of CDCs came from all of the country's provinces, and their presence and diversity of origins expressed the national community to be built.

Tuesday, 13 November was a big day because President Karzai addressed the delegates. Security measures were exacting - everyone had to endure a long wait in the early morning cold and submit to the guards' authoritarianism before being allowed to enter the compound, where huge tents had been set up. Toward 9:00 a.m. the noise of a helicopter sparked a wave of excitement through the crowd and several people rushed to the front rows of seats. But another fifteen minutes passed before Karzai made his entrance-nearly surreptitiously — by way of a lateral access. He shook some hands on his way up to the

\footnotetext{
22 See www.areu.org.af/.
} 


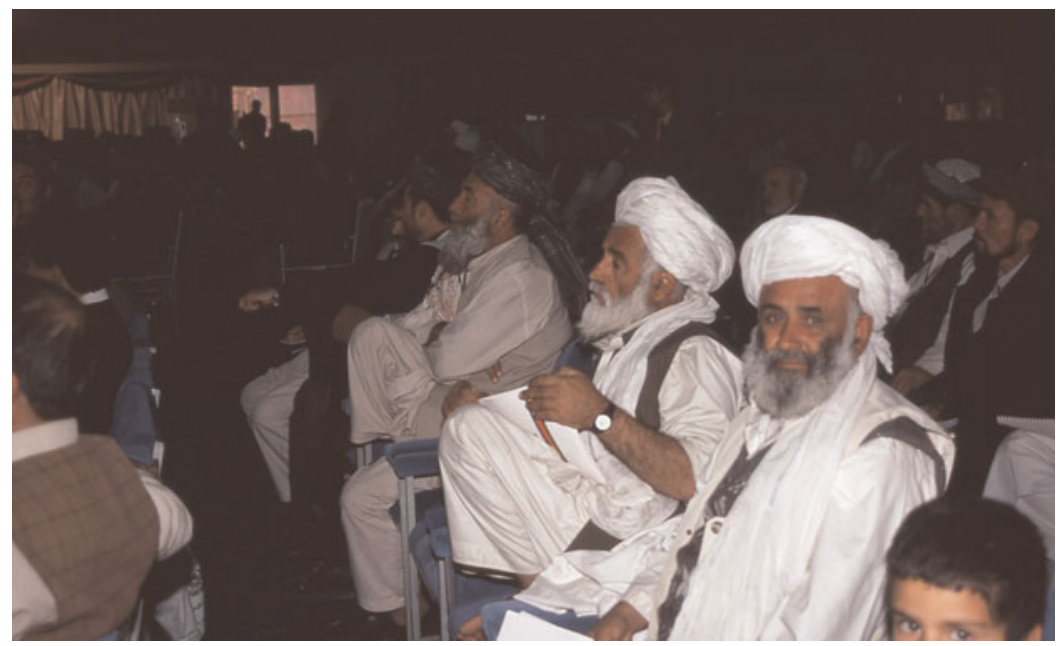

ImAGE 1 CDC representatives attending the NSP conference, November 2007. Author's photo.

stage, accompanied by Minister of Rural Reconstruction Ehsan Zia. Karzai addressed the assembly with intentional simplicity: "Salâm aleikom sâheb, khosh âmadi! (Good morning gentlemen and ladies, you are welcome!)" He made a sign to the audience to take their seats before he sat down at the main desk. Two screens, on either side of the big tent, alternately showed images of the orators and the audience.

Several people spoke, starting with an MRRD representative who talked in Pashto. He was followed by a young man wearing a cream-colored Western suit who recited a surat from the Koran. Finally, a woman dressed in bright yellow delivered a short speech of welcome and then gave the floor to Minister Zia. He, speaking Persian, began with the usual greeting to the members of government, the diplomatic body, and the UN representatives. He sang the NSP's merits, underscoring that for the first time in Afghanistan's history its people (mardom) were taking their destiny into their own hands. He insisted that there was close collaboration between the government and the rural populations across the thirty-four provinces. Some of his statements were punctuated by applause, but his voice was often drowned out by the hum of the helicopters. Several CDC delegates then spoke in Pashto or in Persian, depending upon their geographical origins.

Finally, it was Karzai's turn. The audience rose to its feet, but he immediately signaled for everyone to sit down, adding the ostentatious courtesy, "Merabâni! (It is very kind of you!)." Several times during the speech someone in the audience stood up to manifest his support, sometimes by reading a small note, sometimes in verse. The president began to speak in Persian to greet 
the delegates, and again welcomed them. He referred to a recent bomb attack in which, according to the estimate he had, fifty-nine people had died, including an influential Shia member of parliament. "Ami kâr sâhi nist! (Such an action is not just!)" he thundered, demanding the public's support. He mentioned the diverse geographical origins of the victims, as if to symbolize the country's unity when confronted with blind violence. He shared his grief, but continued by speaking of his hope of seeing the country develop: "Thirty-eight thousand villages are finally benefiting from reconstruction projects." Progress was visible, he imparted a small anecdote to illustrate the country's electrification: "I was returning to Kabul by plane at night and saw numerous small lights on the ground: 'Where are we?' I asked the pilot-'We are flying over Afghanistan!' he answered." This progress, he added, had been possible thanks to the "jam 'a-ye jehâni (international community)" helping Afghans, even if they had committed all kinds of atrocities.

In the middle of his speech, Karzai switched to Pashto before going back to Persian. He mentioned international terrorism, Al-Qaeda, the Talibans, the process initiated at the Bonn conference in late 2001, and the constitution. He paid homage to the victims of jihâd, whose sacrifices had made victory over the Soviets possible and whose numbers had increased year after year. He also spoke of migration, of the Afghan diaspora in London, New York, Washington, Shahjah, Mashhad, and Islamabad, which he said had deprived the country of its living strength: "This should not recur!" Afghanistan, Karzai said, is henceforth "dar râh-e taraki (on the path of progress)." That it was now possible to produce sewing needles was sufficient proof. He took a pen from his waistcoat pocket and showed it proudly to the crowd, declaring it to have been made in Afghanistan. A man in the middle of the hall rose to express enthusiasm. After looking at him, Karzai greeted him in Uzbek, which drew vigorous clapping from the audience. Continuing, Karzai showed a packet of electric switches produced in Herat, and then a cable. The president ended his speech by proclaiming that buying products - and not only melons - made in Afghanistan was a patriotic act. Amid hurrahs, he descended from the stage, made his way toward the audience, shook people's hands, and then proceeded to the women's corner to greet them. Finally he gave a slight bow, and departed. It was now 11.30 a.m.

The alternating use of Persian and Pashto symbolized the country's unity and made clear that it was not composed only of Afghans - a term historically reserved for Pashtuns. It indicated the subtle hierarchy of languages on a national stage: Persian and Pashto for the speeches, with a few sentences in other languages to give them a place, even if a subordinate one. The speech displayed a delicate balance between an appeal to national pride - in his rather discreet reference to the victory over the Red Army-and the recognition of international aid. He also illustrated the tension between the national and supranational levels. On this 2007 occasion, Karzai highlighted the latter by granting 
more attention to the support of the international community than to anti-Soviet resistance. But things changed with the presidential elections of August 2009. Then, accused of benefiting from massive fraud, Karzai fell back on national values and increasingly presented himself as a man struggling to safeguard Afghanistan's sovereignty against Western interference. We will see that his shifting attitudes toward the NSP and local government mirror the evolution of his political alliances.

THE WORKSHOP CULTURE: ACQUIRING A NEW HABITUS

After more than thirty years of regular interaction with UN agencies and NGOs, Afghans have learned to strategically adjust their behaviors and discourse to match what they believe humanitarian and development actors expect to see and hear. But this cannot be reduced to a mere instrumental relation. People's involvement in projects and their recurrent contacts with international aid workers have subtle effects on the way they see themselves and are seen by others. The NSP conference in Kabul was an opportunity for delegates representing CDCs to establish new relationships, perfect their knowledge of procedures, and exchange thoughts and views regarding the strong and weak points of the program. But the conference may also be seen as the setting for acquiring an ethos shared with people working in similar structures across the country, thus strengthening the sentiments of belonging to a particular group that, by its commitment to development, distinguishes itself from the rest of the population. The conference workshops (grupkâri or kâr-e grupi; literally "group work") in particular are places where subjectivities are constructed and negotiated in novel ways.

I attended one of these discussion workshops. The décor was composed of chairs, tables covered with tablecloths, and flip charts. Dressed as a Westerner, I sat in a corner and did not participate in the debates. My presence invited no particular curiosity or questions; CDC members seemed accustomed to having experts of all kinds accompany them in their activities. Some men wore turbans, but many had bare heads. Several women were present, strictly veiled, but none wore the head-to-toe burqa. When the women spoke, the men listened to them, nodding their heads with ostentatious deference.

A delegate from the east of the country, wearing sunglasses, a waistcoat, and a pakul hat, ${ }^{23}$ opened the session with a long prayer in Arabic, and then spoke in Pashto. Another delegate followed who also began with an Arabic prayer (but a shorter one), and then spoke in Persian: "Khwârhâ-ye aziz, berâdarân-e gerami... (Dear sisters, dear brothers...)." He began by extolling the victory of the Afghans over adversity and the defense of religion, then the merits of the NSP, which was bringing services directly to the population and

23 The hat made famous by Ahmad Shah Massud. 


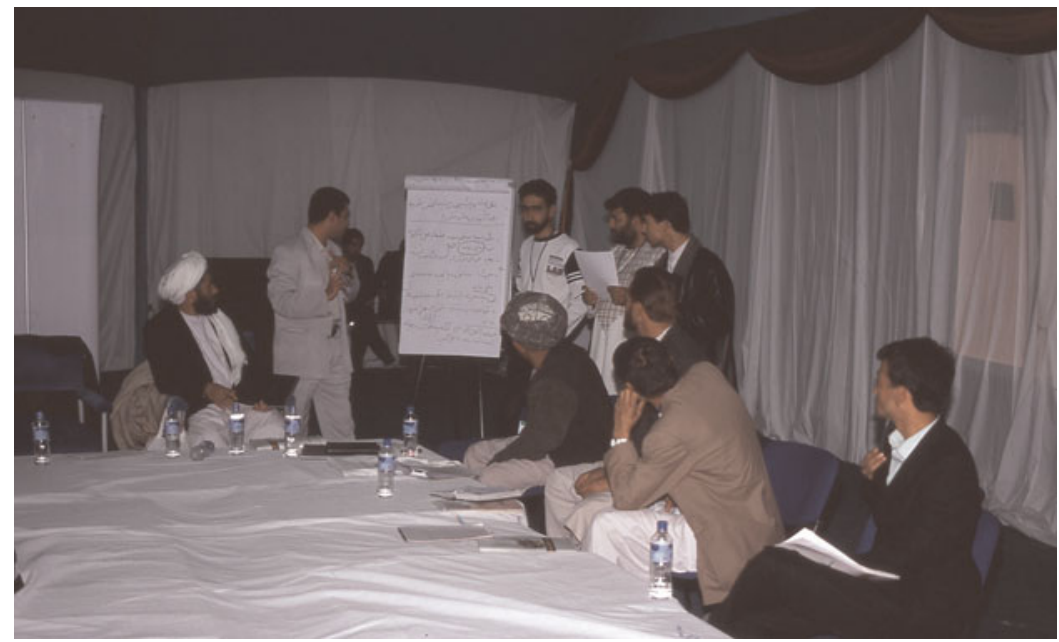

ImAGE 2 The staff of the MRRD and Facilitating Partners animate a workshop using a flip chart, November 2007. Author's photo.

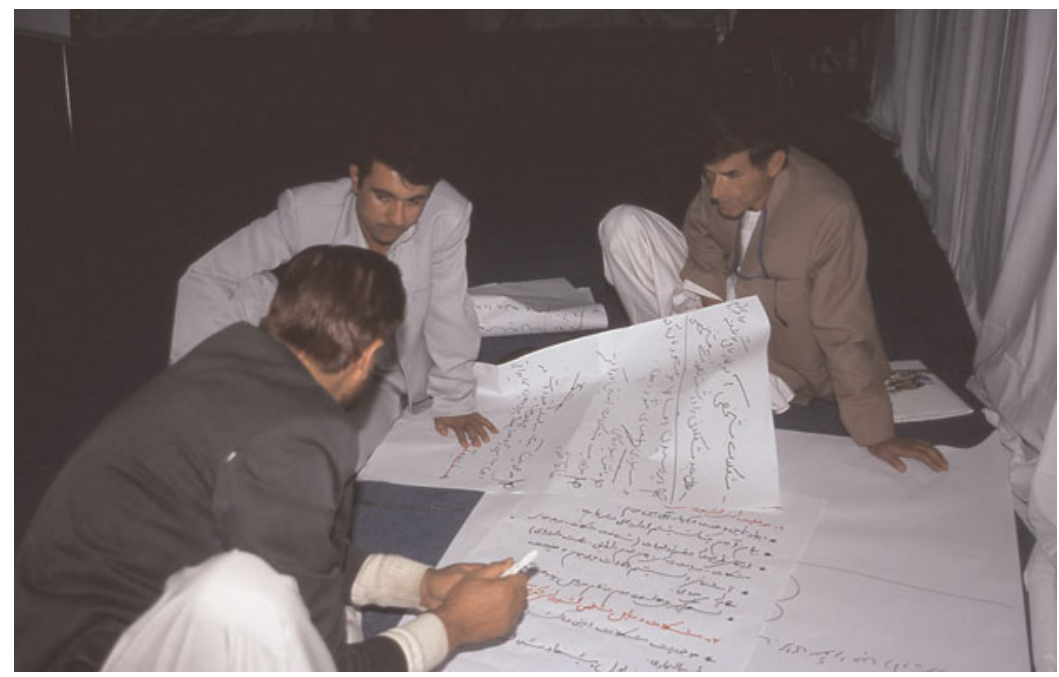

IMAGE 3 The organizers of the workshop having their debriefing, November 2007. Author's photo.

thus sealing the link with the government. The discussion then turned to actions for improvement in the future, particularly the articulation of CDCs and provincial authorities. Other speakers-men and women representing CDCs, and employees of the MRRD or Facilitating Partners - all boasted of the merits 
of the NSP, declaring that the program had brought democracy to the level of villages. Each speaker repeated the same mantras: "wahdat-e mardom (unity of the people)," "taraki-ye mardom (progress of the people)," or "bâzsâzi-ye watan (reconstruction of the homeland)."

The boundary between members of Facilitating Partners and CDCs seemed fuzzy, and I understood, with some surprise, that some people were contradicting the Weberian idea that the bureaucratic form of authority is based on the separation between various offices and a hierarchy of specified competences. The discussion was organized around a flip chart on which staff from the ministry and NGOs had noted the main points addressed, with the idea of carrying them forward to the managing bodies of the NSP. Small secondary groups soon formed. Some people tried to highlight the positive points of the program, limit digressions, and strictly apply the rules of participatory procedure as defined by the NSP. Others, after mouthing conventional rhetorical praises, stated grievances. They complained of receiving insufficient funds to make any real contributions to developing their places of origin, and stressed the need for more ambitious projects planned at a supra-village level, such as roads and district hospitals.

Beyond the content of the debates - mostly technical questions and proposals for improvements - the way in which these workshops were organized and conducted profoundly marked the minds and behaviors of the participants. For those from rural areas, the mere fact of sitting on chairs and, more importantly, the lack of gender segregation were particularly odd. As if to make the situation acceptable and manage their embarrassment, both men and women were extraordinarily polite. Anila Daulatzai has reflected on the handshake dilemma between foreign males and Afghan females, or foreign females and Afghan males, and explains it in this way: "The disappearing of gender segregation in everyday interactions in Kabul implicitly questions Islamic notions of modesty. The discomfort experienced by many Afghans as a result of new forms of proximity between men and women in daily life (as a consequence of international aid efforts in Kabul) should not be seen as remnants of archaic and exploitative gender relations, but as a consequence of fundamental ethical and discursive practices which are tied to what it means to be Muslim and Afghan" (2010: 6).

The delegates used their body language and words to negotiate their multiple identities. They were present as members of CDCs, a development structure that is directly dependent on international aid rather than any administrative entity. Their fealty certainly was to the MRRD and therefore, in theory, to the Afghan state, but also to the World Bank, whose experts had conceived the NSP, and to the international community that was financing it. This constellation brings about subtle changes in modes of socialization, of habitus in Bourdieu's terminology, these systems of long-lasting arrangements, "structuring structure" that organizes social practices and the perception of 
these practices, but also "structured structure" that is influenced by the division of society into various categories. ${ }^{24}$ Despite their differing points of view, all the participants in these workshops agreed on the importance of maintaining the "field" that gave them the possibility of gathering under the loya jirga's tent in the Afghan capital, a place symbolically charged with power. Their link to the NSP brings them resources and status. Members of CDCs, the staff of the MRRD, and various partner NGOs are all interdependent in a certain market. Integration into this market implies the acquisition of specific values or behaviors as well as knowledge of how to implement them. Like any social field, the NSP changes practices and perceptions and produces new distinctions. Obviously, this process is not unidirectional-it takes place in a social space charged with relations of power in which adherence to the principles of NSP does not negate the importance of segmented structures of tribal solidarity or clientele networks set up by local strong men and the parties.

LOCAL POLITICS: THE OVERLAPPING SOURCES OF SOLIDARITY AND CONFLICT

During the NSP national conference, I met the representative of the CDCs from the district of Jaghori, province of Ghazni, where I had conducted fieldwork. A young man with a thin, carefully trimmed mustache, he wore dark trousers, a jacket, and an impeccably white shirt that gave him a modern look. He had recently opened the first Internet café in one of the main bazaars of the district. He had spent time in Iran and Pakistan and had encountered the Internet in Indonesia, where he had traveled, like many Afghans, with the hope of clandestinely entering Australia (Monsutti 2009).

This CDC representative, socialized and educated abroad and connected with the global world by his professional activities, belongs to a new emerging class of men and women whose social and political activities are linked to resources — both material and immaterial — made available by the presence of international and nongovernmental organizations. At the same time, he is a stakeholder in the complex power games of his native region through his link to a resistance commander who was recently expelled by the district chief appointed by the central government. But the NSP does far more than give visibility to people who are, inevitably, involved in factional struggles; it also contributes to redefining the social and political geography of the Afghan rural world.

It is common to find district administrations housed in modest premises, whether a simple shop in the bazaar or a compound dating to the precommunist period. Common sights around these places include an official wearing a turban and sipping a cup of sugarless tea, a Hermes typewriter, or

24 See, for instance, Bourdieu 1979: 191. 
perhaps an old Soviet jeep. What a contrast these are to NGO offices - particularly those benefiting from NSP manna-with their young employees, generators, and Japanese four-wheel-drive vehicles. The ostentatious presence of these organizations, waving the flags of donor countries, tends to make the Afghan state invisible at the local level, confined to the field of police control with its trail of abuses. Such situations illustrate the range of multiple and segmented sovereignties that now characterize Afghanistan as well as many other postcolonial states in Asia and Africa.

The abovementioned district of Jaghori lies on the southern fringes of Hazarajat. $^{25}$ Despite the constant migratory flux there, the demographic pressure remains intense. Farming is hard, and every cultivatable plot of ground is planted. Small terraces are arranged for irrigation using underground canals, and orchards cheer up parts of the landscape. Jaghori's main products are wheat, beans, fruits (apples, apricots, mulberries), and nuts (almonds and walnuts). More than agriculture, though, the economy relies on remittances from men working in the coalmines around Quetta, Pakistan, or doing manual labor in Iran.

The district's boundaries as defined by its inhabitants do not correspond to the maps produced by the Afghanistan Information Management Service. ${ }^{26}$ In local discourses and representations, but also by people's social practices, Jaghori can be divided into more than twenty regions, or manteqa, but these have never been officially acknowledged. Each manteqa consists of several hamlets, or qaria, scattered near the irrigated plots. Many qaria are occupied by more than one descent group, and almost no descent group resides in only one location. In other words, kinship and residence are not congruent. The inhabitants of the region are related by many overlapping obligations. First, membership in a patrilineage comes with a number of duties: to avenge wrongs against agnates, to provide mutual financial aid (for example, in case of marriage, to help assemble the bride payment), and to participate in common celebrations. Agnates share a diffuse solidarity and a feeling of common destiny, while kinship relations through women-mothers, sisters, or wives - are often less compelling and more flexible.

A second obligation comes when the inhabitants of a hamlet together own one or two irrigation canals, and share both the work of their maintenance and rights to the water they bring, following a predefined cycle. These rights are transmitted from one generation to the next along with the land, and are successively divided between the heirs from the time the canal was built. This tight

\footnotetext{
25 Hazarajat is the central part of Afghanistan, inhabited mostly by Persian-speaking Shiites.

26 See www.aims.org.af/. This discrepancy is inconsequential so long as the central government has not the capacity to really implement any land policy, but it will cause frictions in future when the high modernist project of the state — to speak like James Scott (1998) - further reshapes the social and political geography with the support of the development organizations.
} 
cohabitation and interdependence can create conflicts but also demands cooperation. A third obligation comes when several hamlets join efforts to maintain a place for religious gatherings (membar) and pay for the services of a mullah who can ensure Koranic readings and basic teachings (Edwards 1986; Bindemann 1987).

In addition to these ties of solidarity, others have formed due to the endemic insecurity that characterizes social relations and everyday life in Jaghori. Although the region was comparatively untouched by fighting during the Soviet occupation, internal conflicts and sociopolitical upheavals there, as in the rest of the Hazarajat, have been profound and have risen to a level unknown in past tribal warfare. Feuds are sometimes settled through murder, especially now that everyone owns heavy arms such as automatic rifles or even rocket launchers and flame-throwers. The early 1980s witnessed merciless conflicts between two emerging classes of leaders: secular intellectuals, often from well-off families and affiliated to parties of Maoist inspiration, and Khomeinist militants, returning from Iran and generally from more modest sociological backgrounds. During this period, the Khomeinists gained control over most of Hazarajat (Roy 1985: 194-205; Harpviken 1996).

In 1989, the Red Army withdrew from Afghanistan. Hazara leaders feared being excluded from peace talks and understood that unity was their path to salvation. Because of recent disruptions this unity could only be built on a new ideological foundation: Hazara identity. With the active support of Iran, the main Shiite factions strove to bury past conflicts and agreed to form a vast, unitary movement named the Hezb-e Wahdat-e Islami-ye Afghanistan ("Party of the Islamic unity of Afghanistan"). Religious leaders kept the reins of power, but the new party also incorporated many secular intellectuals such as soldiers, engineers, doctors, and teachers who tried to become indispensable and regain a political role by creating NGOs that provided health care and education or built roads.

Against this recent history of conflict, the NSP seeks an ideal level of solidarity in which the interests of everyone converge. Assuming that the jihâdi commanders are discredited among the population, this community-building approach encourages the emergence of a new class of notables who are sensitive to the values of donors, with the ultimate goal of fostering social cohesion and horizontal ties of cooperation in the social fabric of rural Afghanistan. However, in such a tense and fragmented context, the fact that the NSP pays the optimal subsidy of resources to communities of three hundred households is an incentive to division. In the district of Jaghori, as elsewhere in Afghanistan, the number of CDCs set up by the NSP largely exceeds the number of manteqa. In quite a few cases, political factions within each manteqa form distinct CDCs with the goal of independently accessing the resources the program provides. Local politics is structured around a subtle blurring of solidarities and rivalries, because the strongest obligations also entail major sources of tension. 
Unlike the well-known concentric model developed by Sahlins (1965) to account for the social dimensions of exchange, the sphere of general reciprocity in Afghanistan is one in which violence is common.

In the history of Afghanistan, attempts by urban elites to introduce top-down social change have repeatedly met with resistance from rural populations. A certain political stability was achieved during the long reign of Zaher Shah (1933-1973), when the provincial administration representing the central government had neither the capacity nor the political will to quickly transform tribal and village structures (Barfield 2010: 198, 338). The NSP, by contrast, works to reconfigure the social geography of the Afghan rural world to promote an ideal of social harmony and community building, according to which each village should directly receive the resources needed to plan and manage its own development projects. This voluntaristic approach is trapped in a presumption that there must be a diametrical opposition between "bad" commanders - spoilers who impose their arbitrariness - and "good" communities that must be empowered to pursue shared interests. This perspective is at odds with local social organization because it denies both the necessary protection commanders may provide and the fault lines that often characterize communities. Far from being a space of solidarity, local and territorial groups of rural Afghanistan - whether vaguely called "communities" or "villages"- must be conceived as political arenas in which people compete as much as they cooperate for scarce resources: water, land, migration connections, and, last but not least, aid money.

\section{NATIONAL POLITICS: THE STAKES OF RURAL REHABILITATION}

During the 2007 NSP conference there was a quarrel between some representatives of the Ministry of Rural Rehabilitation and Development and others from the Ministry of Agriculture, Irrigation and Livestock (MAIL). The former reproached the latter for being passive; the latter—backed by colleagues in the Ministry of the Interior - accused the former of having become conceited about their privileged relations with international donors and of exceeding their prerogatives. Indeed, the MRRD sought to transform CDCs into a permanent body of local governance "that will take on additional responsibilities beyond NSP as it matures" (NSP 2006: vi). In the meanwhile, the MAIL and Ministry of the Interior considered that the CDCs had encroached on prerogatives of the existing administrative structures.

The contrast between the various ministries in Kabul is embodied in their premises, as well as in the body language of the officials who work in them. Their differences impart lessons for understanding how social relations are critically influenced by access to the funds of the international community. The MAIL is in the war-torn neighborhood of Kart-e Sakhi, and headquartered in an old building still visibly scarred by the combat in 2007. This institution's marginality was expressed by the relatively light security measures there, 
and the civil servants present seemed to rejoice at the arrival of a visitor offering an occasion to exchange words over a cup of tea. The MRRD, on the other hand, occupies a new complex to the south of Kabul near the old Darul Aman Palace constructed in the 1920s by the reformer king Amanullah. The MRRD complex is protected by security measures worthy of a Western airport, and the atmosphere is quite different from that at the MAIL: MRRD occupies various buildings in a well-maintained park, and young, mustached technocrats wearing well-cut jackets seem to be constantly running between appointments. These two places and the officials who inhabit them display the heterogeneity of the Afghan state apparatus and illustrate how various ministries are differently integrated into the international development regime. The MAIL, ${ }^{27}$ which before 1978 was the center of gravity of development plans, has been relegated to the sidelines, while the newer MRRD ${ }^{28}$ has connected successfully to the contemporary world of NGOs and has prospered. The MRRD became a key ministry by attracting important funds from Western donors through the NSP and other reconstruction programs, and by placing a huge number of employees around the country, thereby extending the reach of its patronage networks.

Internal diversity and competition do not prevent elites from circulating between the diverse structures of the Afghan state: Mohammad Hanif Atmar, one of the promoters of the NSP and, from 2002 to 2006, the Minister of Rural Rehabilitation and Development, acted as Minister of Education ${ }^{29}$ from 2006 to 2008 before becoming the Minister of the Interior. Mohammad Asif Rahimi, vice-minister of MRRD in 2007, became the Minister of Agriculture in 2008. Moreover, many Afghans as well as international experts credit Hanif Atmar with presidential ambitions. It is said that the MRRD will have served him as a springboard to develop political clientele across the national territory, and his name will remain attached to a period of optimism and the expansion of the NSP. To dampen such personal ambitions Karzai quickly rotates officials through positions so that they cannot solidify relations of patronage within the administration of certain ministries and provinces. ${ }^{30}$

While the disagreement between the MRRD, the Ministry of the Interior, and the MAIL about the role of the CDCs was at its height, the Independent

\footnotetext{
27 After several changes, it is currently named the Ministry of Agriculture, Irrigation and Livestock (MAIL). It has been since 2009 in a process of reform so that it can compete better in the evolving context: http://mail.gov.af/en/page/104.

${ }^{28}$ Created in the 1950s as the Rural Department Commission, the MRRD has been under the authority of various ministries and became an independent body only in 1988. It was reestablished with a broader mandate in 2002 after the fall of the Taliban, and quickly moved into new buildings: http://mrrd.gov.af/en/page/65.

29 The Ministry of Education is also very powerful, and has staff in every district of Afghanistan.

30 District chiefs and provincial governors are similarly circulated. This permits Karzai to redistribute positions and, consequently, resources to his allies and clients while preventing them from forming stable political strongholds.
} 
Directorate for Local Governance (IDLG) was established by presidential decree, on 30 August 2007. This move expressed a centralization of power - the responsibility of supervising provincial governors, district chiefs, and provincial and municipality councils was withdrawn from the Ministry of the Interior and entrusted to the new office. Its explicit mission was to connect people with the government and achieve significant improvements in service delivery at the subnational level. By establishing the Independent Directorate, Karzai also seems to have deferred-without definitively disavowing - the ambitions of the Ministry of Rural Rehabilitation and Development. Some leaders of the new entity, narrowly linked to Karzai, reproached the MRRD for going it alone and not coordinating with the rest of the government. They initially opposed the idea of CDCs transforming themselves into administrative structures of local governance and adhering to the text of the 2004 Constitution that foresees free, general, secret, and direct elections of village, district, and municipal councils for a period of three years (IDLG 2007). ${ }^{31}$ From their perspective, the CDCs were but one institutional partner among many and should not aspire to be more than bodies emanating from civil society, responsible primarily for development projects. The situation has changed yet again since the Third Community Development Councils National Consultation Conference, organized in October 2010 by the MRRD. After much deliberation, in 2011 a resolution signed by five ministers was submitted to the office of the President requesting that $\mathrm{CDCs}$ should be given the role of the constitutionally sanctioned Village Councils.

Beyond the rhetoric of improving coordination and promoting good governance, security, development, and economic growth, the creation of IDLG reflects Karzai's desire to work closely with different power bases while keeping a delicate balance between various political actors and institutions. This is consistent with his strategy to back several horses and regularly shuffle his cabinet. At the very moment he praised the support of the international community during the 2007 conference of CDCs he was maneuvering behind the scenes to form a large coalition with an eye to the future presidential elections. In the hope of stabilizing the country's rural regions, traditional rural elites and jihâdi commanders were considered a better vehicle for gaining votes through patronage than were young educated people committed to the principles of democracy and human rights. The context was evolving quickly; international organizations had presented the 2004 presidential elections as a moral defeat for the Taliban, and the vote had created a wave of optimism, but after 2006 the insurgency gained ground in the south.

In the meantime, Karzai's relation with the U.S. administration, from which many voices criticized his poor record of achievement, deteriorated.

\footnotetext{
${ }^{31}$ See more specifically Articles 137-141 of the 2004 Constitution of Afghanistan (Islamic Republic of Afghanistan, Office of the President: http://president.gov.af/sroot_eng.aspx?id=68).
} 
He had always displayed a strong preference for a centralized government and feared the rise of regional centers of power. During the presidential election campaign of 2009, Karzai responded to new political and military challenges by adopting a strategy of recruiting people labeled as "warlords." His international backers disapproved (Barfield 2010: 331). This political realignment became apparent when Karzai won the support of several historic war leaders who had once been hostile toward him, such as Abdul Rashid Dostum and Haji Mohammad Mohaqiq. After the elections, which were marred by allegations of massive fraud, tensions heightened between Karzai and the foreign powers present in the country. This was one facet of the shifting relations between the Afghan government and its international protectors.

In such a quickly changing atmosphere, it can seem that the NSP's momentum has faded. The program is still celebrated by the government and the donors as an example of success, but its political importance has decreased-possibly temporarily_as alliances have been repositioned and redefined. Nevertheless, the case of the NSP shows that humanitarian assistance is now part of Afghan politics and plays a key role in the fluidity of sovereignty. Foreign assistance is one of the resources that political actors try to deploy in their struggles for power.

RESHAPING SOVEREIGNTY: TRANSNATIONALIZATION AND

DEPOLITICIZATION OF POWER

We have seen that various transnational networks channel resources that contribute to multilayered sovereignty in various countries. But nowhere do they appear to have reached the same scale over such a long period as in Afghanistan. Afghanistan is thus a somewhat extreme case, but it illustrates broader patterns nonetheless.

Through migratory networks millions of people circulate between Afghanistan, Pakistan, Iran, the countries of the Arabian Peninsula, and the West. These migrants bring money and skills but they also contribute to the rise of new political claims. Trading networks range from those that import everyday commodities, which are partly funded by the money of refugees and migrants, to those of the narcotic economy, whose impact on Afghan society and politics would be difficult to exaggerate. Non-state, armed networks are formed by the insurgency and its worldwide sympathizers, and by private security firms contracted by humanitarian and development organizations, business companies, and even national military forces. Strictly speaking, we must consider foreign troops in Afghanistan to be situated at an interstate level, not as a transnational phenomenon. But the boundaries are fuzzy; the U.S., British, Turkish, and other armies present in the country are surrounded by a world of private companies that take care of their logistics, catering, and entertainment. We need to explore their involvement in the reconstruction effort and their impact on Afghan society beyond the basic providing of security. They all 
are now part of the national political landscape and they exist in tension with state sovereignty.

I have elsewhere examined how migration, remittance, and smuggling are interconnected phenomena (Monsutti 2004; 2005), but in this paper I have focused on humanitarian action and development. My main subject here, the NSP, is one of many "schemes to improve the human condition" studied by James Scott (1998), and is an expression of the "will to improve" described by Tania Murray Li (2007). The rationale of such a development program is to convince rather than to coerce, and this gives full significance to the concept of "governmentality." The will to improve is translated into explicit programs via two steps that correspond to the CDC's main tasks: to identify the needs and the problems requiring solutions, and to translate these problems into technical terms. The process renders the issues involved nonpolitical. Indeed, as James Ferguson has shown, the development apparatus is an "antipolitics machine" (1994) that reduces poverty to a technical problem. It fails to address political-economic questions related to the control of the means of production and the structure of inequalities, and it eventually contributes to the expansion of state bureaucracy and power. Humanitarian and development experts in their planning and actions often overlook political structures that produce and reproduce inequalities of status, wealth, and power. Poverty tends to be considered an unfortunate condition rather than the result of asymmetrical relations - vulnerable people can be empowered simply by identifying and supporting them.

The NSP illustrates how programs to educate and train people are conducted with little understanding of the social structures of which those people are a part. Many observers have stressed the limitations of these development programs that emphasize community participation and empowerment. According to Li: "First, they pay astonishingly little attention to the character of ruling regimes, which they continue to treat as development partners desiring only the best for their citizens.... Second, they pay very little attention to the power relations implicit in their own self-positioning... Third, these interventions continue to exclude structural sources of inequality from their technical domain and focus upon an incarcerated 'local' in which properly guided villagers are expected to improve their own conditions by their own efforts" (2007: 275-76).

Although Li's words were inspired by research on the highlands of Sulawesi, they also accurately describe the NSP in Afghanistan. But development programs are not abortive schemes; they are fragments of reality, which have specific effects on the social lives of millions around the world. The primary goal of the NSP planners has been to enhance local communities' capacity for action, and to give them the ability to define their own development priorities. The official discourse of the NSP's different institutional partners tends to display an apologetic tone, but the real impacts that its various projects have 
had on everyday lives are debatable. While there is no doubt that bridges have been built and wells dug with resources the NSP has channeled, we must ask if the program has truly created better living conditions for rural people. Has it brought more social justice, or more economic and political equality? Has it enhanced transparency and popular participation?

The significance of a project such as the NSP reaches far beyond its explicit intentions. Such projects must be considered beyond their successes or failures in terms of post-conflict reconstruction and development. The NSP contributed to the expansion into the rural regions of a pyramidal bureaucracy with national and international elements intermingled..$^{32}$ During the 2004 presidential election, the NSP was much celebrated by Hamid Karzai. Its political importance subsequently faded with the realignment of alliances that preceded the 2009 election. Despite having lost momentum, the NSP continues to serve the central government as a means for it to become more visible at the local level. As an Afghan interlocutor once told me with a disenchanted detachment, "It was a subsidy given by the international community to Karzai's first presidential campaign." State power in Afghanistan, burdened as it is by both its dependence on the foreign presence and the progress of the insurgency, is weak. But the NSP remains one element in the vast humanitarian and development apparatus that works to teach new skills, terminologies, desires, and bodily gestures. Its overarching ambition is to reconfigure the subjectivity of people and to ultimately transform social relations and personal aspirations. Unlike colonial regimes, the international and nongovernmental organizations do not control means of coercion, but they do channel resources, provide jobs, and grant social status.

The workshops the NSP organizes at different levels target a group of entrepreneurial people who are expected to become important players in social change by passing on the message to others at lower levels. Beyond the technical dimensions of the training, these workshops also convey attitudes such as desires for participatory democracy, aversion to corruption, and disavowal of gender segregation. Although it is difficult to evaluate the extent to which workshops achieve these goals, their terminology and concepts percolate throughout society. No Afghan today ignores the meanings of "democracy," "human rights," "gender," "workshop," or "nongovernmental organizations."

If we take Ferguson and Gupta's perspective on transnational governmentality (2002), then the idea that there is a vertical relation between the state, civil society, local communities, and families is misleading. As is often

32 Similarly, the project in Lesotho described by Ferguson has been a development failure, but it allowed the government to gain control over the opposition strongholds in the mountains: "It did not bring about 'decentralization' or 'popular participation,' but it was instrumental in establishing a new district administration and giving the Government of Lesotho a much stronger presence in the area than it had ever had before" (1994: 252). 
acknowledged in the development literature, the grassroots dimension of many associations of so-called civil society is tenuous due to their dependence on international donors. Organized in what appear to be horizontal networks spanning national borders, these associations and their animators deploy a discourse of human rights, democracy, and legibility. The subtle and often not so subtle problem of their popular representation and legitimacy go unnoticed. Although the programs they implement differ from the centralized planning projects described by Scott (1998), it appears that the high modernist project of rationalizing human life is no longer pursued exclusively by states; it has increasingly been taken over by overlapping transnational networks that carry out state-like practices across various polities. These transnational networks, as we have seen, channel resources that may be used in social and political struggles. In places like Afghanistan and many other postcolonial states in Asia and Africa, the presence of alternative and sometimes competing resource suppliers contributes to a vast range of multiple and segmented de facto sovereignties. By implementing state-like programs, transnational institutions contribute to the emergence of new forms of sovereignty.

We must ask whether the proliferation of NGOs forming global power networks undermines the nation-state as the principal vehicle of sovereign power. It is frequently announced that we now face the ultimate crisis of the nationstate, but the situation is more complex than that, and not fully novel. As Hansen and Stepputat observe, the nation-state has probably never been "the privileged locus of sovereignty" in much of the colonial and postcolonial world, where "sovereignties are found in multiple and layered forms" (Hansen and Stepputat 2006: 309). ${ }^{33}$ For Hansen and Stepputat (2005; 2006), sovereignty should not be studied as an ontological space of power and order. They advocate instead an ethnographic, practice approach to sovereignty that includes the study of informal structures of illegal networks, strongmen, insurgents, vigilante groups, and, we must add, foreign troops. Such a research agenda must also include the study of humanitarian and development programs that participate in "an ostensibly depoliticized government in the name of scientific rationality and improvement of the life of citizens and populations" (Hansen and Stepputat 2006: 302).

The Afghan state never monopolized legitimate power on its territory. It has a long history of external influences - reaching back to nineteenth-century British subsidies - that have both limited and enhanced its sovereignty. The national government today, with little revenue of its own and facing a high level of internecine competition between various ministries and offices, can build some legitimacy by its association with international aid distribution. The state is spatialized, in a very concrete way, into distinct territories. As

\footnotetext{
${ }^{33}$ Postcolonial states are characterized by what Hansen and Stepputat call "outsourced sovereignty" (2006: 307).
} 
much for transnational institutions as for the national population, civil servants are indispensable intermediaries due to their ability to traverse spatial and administrative barriers. Stoler has noted that different degrees of sovereignty and a fuzziness of rights are not new phenomena; they also characterized colonial empires (2006). With the homogenization of the world's political geography since the end of the colonial empires, and the emergence of new forms of transnational governmentality, a new relationship has emerged: a layered and divided state apparatus with multiple and segmented de facto sovereignties that does not prevent the pervasiveness of the nation-state as the organizer of international politics. The most striking development in today's world may be, not the much-proclaimed end of the nation-state, but rather the coexistence of states and transnational governmentality.

\section{REFERENCES}

Abou Zahab, Mariam and Olivier Roy. 2003. Islamic Networks: The Pakistan-Afghan Connection. London: Hurst \& Co.

ACTED. 2007. Transition Strategy and Cycle 2+ Communities: A Study of NSP. Kabul: Agency for Technical Cooperation and Development.

Afghanistan Research and Evaluation Unit. 2004. The A to Z Guide to Afghanistan. 3d ed. Kabul: Afghanistan Research and Evaluation Unit.

Barakat, Sultan. 2006. Mid-Term Evaluation Report of the National Solidarity Programme (NSP), Afghanistan. York: Post-war Reconstruction and Development Unit, University of York.

Barfield, Thomas. 2010. Afghanistan: A Cultural and Political History. Princeton: Princeton University Press.

Beath, Andrew, Fotini Christia, Ruben Enikolopov, and Shahim Ahmad Kabuli. 2010. Estimates of Interim Program Impact from First Follow-Up Survey: Randomized Impact Evaluation of Phase-II of Afghanistan's National Solidarity Programme (NSP). S.1.: s.n. At: http://www.nsp-ie.org/reportsimpacts.html.

Bhatia, Michael and Mark Sedra. 2008. Afghanistan, Arms and Conflict: Armed Groups, Disarmament and Security in Post-War Society. London and New York: Routledge.

Bindemann, Rolf. 1987. Religion und Politik bei den schi'itischen Hazâra in Afghanistan, Iran und Pakistan. Occasional Paper 7. Berlin: Ethnizität und Gesellschaft.

Bourdieu, Pierre. 1979. La distinction: Critique sociale du jugement. Paris: Minuit.

Brick, Jennifer. 2008. The Political Economy of Customary Organizations in Rural Afghanistan. Madison: Department of Political Science, University of Wisconsin, MS.

Colville, Rupert. 1998. Afghan Refugees: Is International Support Draining Away after Two Decades in Exile? Refuge 17, 4: 6-11.

Cooley, John K. 2000. Unholy Wars: Afghanistan, America and International Terrorism. London: Pluto Press.

Danspeckgruber, Wolfgang and Robert P. Finn, eds. 2007. Building State and Security in Afghanistan. Princeton: Lichtenstein Institute of Self-Determination, Woodrow Wilson School of Public and International Affairs.

Daulatzai, Anila. 2010. Giving Afghans a Hand: Gender and Ethical Practice in Kabul. Baltimore: Johns Hopkins University, MS.

Devji, Faisal. 2005. Landscapes of the Jihad: Militancy, Morality, Modernity. London: Hurst \& Co. 
Devji, Faisal. 2008. The Terrorist in Search of Humanity: Militant Islam and Global Politics. London: Hurst \& Co.

Edwards, David B. 1986. The Evolution of Shi'i Political Dissent in Afghanistan. In Juan R. I. Cole and Nikki R. Keddie, eds., Shi'ism and Social Protest. New Haven and London: Yale University Press, 201-29.

Edwards, David B. 2010. Counterinsurgency as a Cultural System. Small War Journal, 27 Dec. At: smallwarsjournal.com.

Eisenhower, Study Group. 2011. The Costs of War since 2001: Iraq, Afghanistan, and Pakistan-Executive Summary. Providence, R.I.: Watson Institute for International Studies, Brown University. At: http://costsofwar.org.

Ferguson, James. 1994. The Anti-Politics Machine: "Development," Depoliticization, and Bureaucratic Power in Lesotho. New York: Cambridge University Press.

Ferguson, James and Akhil Gupta. 2002. Spatializing States: Towards an Ethnography of Neoliberal Governmentality. American Ethnologist 29, 4: 981-1002.

Hanifi, Shah Mahmoud. 2011. Connecting Histories in Afghanistan: Market Relations and State Formation on a Colonial Frontier. Stanford: Stanford University Press.

Hansen, Thomas Blom and Finn Stepputat, eds. 2005. Sovereign Bodies: Citizens, Migrants, and States in the Postcolonial World. Princeton and Oxford: Princeton University Press.

Hansen, Thomas Blom and Finn Stepputat. 2006. Sovereignty Revisited. Annual Review of Anthropology 35: 295-315.

Harpviken, Kristian Berg. 1996. Political Mobilization among the Hazara of Afghanistan, 1978-1992. Rapport 9. Oslo: Department of Sociology.

Independent Directorate for Local Governance. 2007. Strategic Framework. Kabul: IDLG, Islamic Republic of Afghanistan.

Johnson, Gregory, Vijaya Ramachandran, and Julie Walz. 2011. The Commanders Emergency Response Program in Afghanistan: Refining U.S. Military Capabilities in Stability and In-Conflict Development Activities. CGD Working Paper 265. Washington, D.C.: Center for Global Development. At: http://www.cgdev.org/ content/publications/detail/1425397.

Jones, Seth G. 2009. In the Graveyard of Empires: America's War in Afghanistan. New York: W. W. Norton.

Li, Tania Murray. 2007. The Will to Improve: Governmentality, Development, and the Practice of Politics. Durham: Duke University Press.

Marsden, Peter. 1998. The Taliban: War, Religion and the New Order in Afghanistan. Karachi, Lahore, and Islamabad: Oxford University Press; London and New York: Zed Books.

Monsutti, Alessandro. 2004. Cooperation, Remittances, and Kinship among the Hazaras. Iranian Studies 37, 2: 219-40.

Monsutti, Alessandro. 2005. War and Migration: Social Networks and Economic Strategies of the Hazaras of Afghanistan. New York and London: Routledge.

Monsutti, Alessandro. 2009. Itinérances transnationales: Un éclairage sur les réseaux migratoires afghans. Critique Internationale 44: 83-104.

National Solidarity Programme. 2006. Operational Manual. Kabul: Ministry of Rural Rehabilitation and Development.

Nixon, Hamish. 2008. Subnational State-Building in Afghanistan. Kabul: Afghanistan Research and Evaluation Unit.

Pétric, Boris-Mathieu. 2005. Post-Soviet Kyrgyzstan or the Birth of a Globalized Protectorate. Central Asian Survey 24, 3: 319-32.

Rashid, Ahmed. 2002. Taliban: Islam, Oil and the New Great Game in Central Asia. London and New York: I. B. Tauris. 
Rimli, Lisa and Susanne Schmeidl. 2007. Private Security Companies and Local Populations: An Exploratory Study of Afghanistan and Angola. Berne: Swisspeace.

Rotberg, Robert I., ed. 2007. Building a New Afghanistan. Cambridge: World Peace Foundation; Washington, D.C.: Brookings Institution Press.

Roy, Olivier. 1985. L'Afghanistan: Islam et modernité politique. Paris: Seuil.

Roy, Olivier. 2004. L'Islam mondialisé. Paris: Seuil.

Sahlins, Marshall. 1965. On the Sociology of Primitive Exchange. In Michael Banton, ed., The Relevance of Models for Social Anthropology. London: Tavistock Publications, 139-236.

Schetter, Conrad. 2005. Ethnoscapes, National Territorialisation, and the Afghan War. Geopolitics 10: 50-75.

Scott, James C. 1998. Seeing Like a State: How Certain Schemes to Improve the Human Condition Have Failed. New Haven: Yale University Press.

Semple, Michael. 2009. Reconciliation in Afghanistan. Washington, D.C.: United States Institute of Peace Press.

Stoler, Ann Laura. 2006. On Degrees of Imperial Sovereignty. Public Culture 18, 1: $125-46$.

Tarzi, Amin. 2008. The Neo-Taliban. In Robert D. Crews and Amin Tarzi, eds., The Taliban and the Crisis of Afghanistan. Cambridge and London: Harvard University Press, 274-310.

UNODC. 2011. World Drug Report 2011. Vienna: United Nations Office on Drugs and Crime.

\begin{abstract}
This paper contributes to the study of new forms of transnational power constituted by the action of international and nongovernmental organizations, to which gravitate loose networks of activists variously promoting democracy, human rights, the empowerment of women, and environmental conservation. The paper's focus is impacts that the massive reconstruction effort is having on Afghan society, examined through a case study of The National Solidarity Programme (NSP), the main project of rural rehabilitation underway in the country. Launched in 2003, its objective is to bring development funds directly to rural people and to establish democratically elected local councils that will identify needs, and plan and manage the reconstruction. Although the NSP's political significance faded in the context of the presidential elections of 2009, which were characterized by quickly evolving alliances, the program illustrates how reconstruction funds are an integral part of Afghanistan's social and political landscape. My arguments are four-fold: First, the NSP subtly modifies participants' body gestures and codes of conduct. Second, the program's fundamental assumptions are at odds with the complex social fabric and the overlapping sources of solidarity and conflict that characterize rural Afghanistan. Third, the ways in which political actors use material and symbolic resources channeled through the NSP mirror national struggles for power. Finally, such programs are one element in a much larger conceptual and bureaucratic apparatus that promotes new forms of transnational governmentality that coexist with and sometimes challenge the more familiar, territorialized expressions of state power and sovereignty.
\end{abstract}

